IMDS

110,9

1420

Received 16 April 2010

Revised 15 June 2010

Accepted 21 July 2010

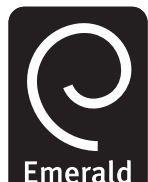

Industrial Management \& Data Systems

Vol. 110 No. 9, 2010

pp. $1420-1443$

(C) Emerald Group Publishing Limited 0263-5577

DOI $10.1108 / 02635571011087464$

\section{The effect of service convenience on post-purchasing behaviours}

\author{
Kuo-Chien Chang
}

Department of Sports, Health and Leisure, Chihlee Institute of Technology, Banciao, Taiwan, Republic of China

$\mathrm{Mu}-\mathrm{Chen}$ Chen

Institute of Traffic and Transportation, National Chiao Tung University, Taipei, Taiwan, Republic of China

Chia-Lin Hsu

Department of Business Administration,

National Taiwan University of Science and Technology, Taipei,

Taiwan, Republic of China, and

Nien-Te Kuo

Department of Tourism Management, Ming Chung University,

Taipei, Taiwan, Republic of China

\begin{abstract}
Purpose - This paper attempts to investigate the casual relationships among service convenience, perceived service value, perceived service guarantee strength, customer satisfaction, and loyalty. Although previous studies have addressed the importance of these variables, the understanding of the mediating effect of customer-perceived service value and the moderating effect of customer-perceived service guarantee strength on customer post-purchasing behaviours still remain key issues.

Design/methodology/approach - A statistical analysis of the collected questionnaires was computed based on the 498 usable responses from the four branches of the selected Chinese chain restaurant. Structural equation modelling is the essential analysis methodology used to examine the hypothesised relationships among the variables.

Findings - Analysis confirms that customer satisfaction is positively influenced by service convenience, whereas customer loyalty is positively influenced by customer satisfaction. Furthermore, customer satisfaction is indirectly influenced by service convenience through perceived service value. Finally, another key finding is the relationship between service convenience and customer satisfaction, which is stronger for customers who perceive high service guarantee strength than for those who perceive low service guarantee strength.

Originality/value - The study contributes to a conceptual model that, reflecting the mediating role of customer-perceived service value and the moderating role of customer-perceived service guarantee strength, indicates the effect of service convenience on customers' post-purchasing behaviours.
\end{abstract}

Keywords Customer satisfaction, Customer loyalty, Service levels, China, Individual behaviour Paper type Research paper

This work was supported by the National Science Council of Taiwan, Republic of China, under the grant NSC-99-2410-H-263-005-SSS. 


\section{Introduction}

Since their rapid growth in numbers beginning in the 1980s, dual-wage families have been seen as seeking products and services that can save them time and effort (Brown, 1990). This phenomenon indicates that the service convenience a business offers may reveal market opportunities that can lead to higher returns and competitive advantages (Seiders et al., 2000). Colwell et al. (2008, p. 165) note that, "In homogeneous markets, where service offerings are similar and therefore not key competitive differentiators, providing greater convenience may enable a competitive advantage". Previous researchers have proposed certain important relationships linked to service convenience; for example, service convenience can directly affect customer satisfaction (Seiders et al., 2000; Berry et al., 2002; Colwell et al., 2008) and lead to customer loyalty (Fornell et al., 1996; Chow et al., 2007). Therefore, understanding the relationships between service convenience and the related variables that affect customer behaviour is the main concern of this study. This study will introduce two variables - perceived service value and perceived service guarantee strength - that combine with service convenience to exert a joint influence on a customer's post-purchasing behaviours. Perceived service value is proposed as a mediating variable while perceived service guarantee strength is proposed as a moderating variable. Both are explored to verify their roles in the relationship between service convenience and customers' post-purchasing behaviours.

Clarifying perceived service value is crucial because perceived value reflects the perspective of the customer. Only the customer, not the seller or the service provider, can determine whether a product or a service offers value (Roig et al., 2006; Cockrill et al., 2009). That is, customer-perceived service value appears as a trade-off between the benefits and the sacrifices perceived by the customer in a supplier's offerings (Ulaga and Chacour, 2001). Thus, a customer-perceived service value is created when the customer perceives that the benefit of consuming products/services (e.g. quality) exceeds the sacrifice (e.g. price) (Zeithaml, 1988; Slater and Narver, 2000; Sweeney and Soutar, 2001; Nasution and Mavondo, 2008), which, in turn, is believed to be the necessary variable that gives rise to behaviours such as satisfaction (McDougall and Levesque, 2000; Lee et al., 2005; Chen and Tsai, 2007; Wang et al., 2009). Although researchers have identified the major driving factors of customer satisfaction (such as service convenience and perceived service value), the interrelationships among these constructs have not yet been investigated. Therefore, this study takes the construct of customer-perceived service value into account to verify its mediating role in the relationship between service convenience and customer satisfaction.

Moreover, the role of customer-perceived service guarantee strength is important because, as Hays and Hill (2006, p. 753) argue:

[...] service guarantee strength measures the strength of the firm's commitment to offering consistent, high quality service to its customers and recovering customers who experience a service failure, with or without a written service guarantee.

Thus, unlike previous studies that have treated service guarantees as explicit operation strategies or activities used to credibly signal high quality to customers (Tucci and Talaga, 1997) and studies that have mainly focused on such guarantees' direct effect in promoting service offerings (McDougall et al., 1998; Hays and Hill, 2001; Marmorstein et al., 2001), this paper aims to explore the role of perceived service

\section{The effect of service convenience}

1421 
IMDS

110,9

1422 guarantee strength as an implicit moderating variable in the relationship between service convenience and customer satisfaction. In other words, this paper treats service guarantee strength as implicit and perceived by customers no matter whether there is an explicit service guarantee expressed (Hays and Hill, 2006). Therefore, this study concerns the customer's perception of a firm's service guarantee strength, which should be understood as part of the relationship between service convenience and customer post-purchasing behaviour.

In light of the current gaps in the literature, understanding the relationships that exist between the constructs of service convenience, perceived service value, and perceived service guarantee strength and their effects on customer post-purchasing behaviours is a key concern in this study that requires further investigation. The remainder of the paper is organised as follows. First, with the purpose of creating a service convenience causation model, the relevant literature on the relationships among service convenience, perceived service value, perceived service guarantee strength, customer satisfaction, and customer loyalty are reviewed. Then, the hypotheses with the conceptual model relating the constructs studied in this research are presented and discussed. The research method and main results are examined in the third and fourth sections, respectively. Conclusions, implications, and future research directions are presented in the last section.

\section{Theory background and hypothesis}

Post-purchasing behaviour

Kotler and Armstrong (2004, p. 201) define post-purchasing behaviour as "the stage of the buyer decision process in which consumers take further action after purchase, based on their satisfaction or dissatisfaction". Therefore, as proposed by Bearden and Teel (1983), "customer satisfaction is a post-purchase event indicating how much the customer likes or dislikes the service after experiencing it" (Lee et al., 2004, p. 71). Thus, managers are interested in customer satisfaction because it is a strong predictor of loyalty (Tuu and Olsen, 2009) that can bring enormous benefits to a company (Brunner et al., 2008). According to Oliver (1997, p. 392), loyalty is "a deeply held commitment to rebuy or repatronise a preferred product/service”. Because customer satisfaction and customer loyalty are important constructs of post-purchase behaviour (Eggert and Ulaga, 2002), their association with service convenience and perceived service value are discussed in the study.

\section{The relationships among service convenience, customer satisfaction, and customer} loyalty

A service provider that hopes to improve its level of customer-perceived service quality must provide service convenience to its customers (Berry et al., 2002; Liang and Wang, 2006). Morganosky (1986, p. 37) defines service convenience as "the ability to accomplish a task in the shortest amount of time with the least expenditure of human energy". In other words, saving time and effort is the benefit of a convenient service and the reason the customer is interested in the service (Brown, 1990). Therefore, by understanding the forms of convenience they can offer, businesses such as retailers can formulate convenience strategies that support lasting customer relationships and raise their competitiveness to new levels (Seiders et al., 2000). Discussions about service 
convenience practices are varied in the literature, but Berry et al. (2002, pp. 11-12) have summarised the five forms of service convenience as follows:

(1) Decision convenience addresses consumers' perceptions concerning the time and effort they have expended to make service purchases or use decisions.

(2) Access convenience addresses consumers' perceptions concerning the time and effort they have expended to initiate service delivery.

(3) Transaction convenience addresses consumers' perceptions concernng the time and effort they have expended to effect a transaction.

(4) Benefit convenience addresses consumers' perceptions concerning the time and effort they have expended to secure the service's core benefits.

(5) Post-benefit convenience addresses consumers' perceptions concerning the time and effort they have expended in order to reinitiate contact with the service provider after the benefit stage of the service.

Since customer satisfaction results when a customer's perception of a given service encounter lives up to his expectations for that encounter (Oliver, 1980; Weiss et al., 2005), the five dimensions of service convenience reflect the activities that customers engage in during the acquisition and consumption of services (Berry et al., 2002) and that tend to dominate customer satisfaction with a business. The more customers experience necessary and relevant service convenient events, the stronger their satisfaction with the business will be. Keaveney (1995) argues that service inconvenience will lead to a customer switching his behaviour. Therefore, service providers need to remain conscious of the positive implications of convenience for customer value and loyalty (Berry et al., 2002). If customers experience a high degree of service convenience, they will feel satisfied with the service provider.

Customer satisfaction is a critical business requirement that could have a significant effect on customers' intentions to repurchase (He and Song, 2009) and, therefore, could affect a company's market share (Sit et al., 2009). In other words, as proposed by Oliver (1993):

[...] a customer's behavioural intention of repurchase is preceded by customer satisfaction which is directly affected by disconfirmation resulted between a customer's pre-purchase expectations and post-purchase performance of a product or service (Chen et al., 2009, p. 1249).

Thus, only when there is total customer satisfaction with the services offered will patrons return to consume the product or service again (Garbarino and Johnson, 1999). Consequently, customer satisfaction directly and positively influences customer loyalty towards a given business (Fornell et al., 1996; Roig et al., 2009). Lee et al. (2008, p. 56) define customer loyalty as "the likelihood of future repurchase or renewal for the current service provider". Within the subject of customer loyalty, we can distinguish the aspect of behaviour from the aspect of attitude aspect, called behavioural loyalty and attitudinal loyalty, respectively, (Reich et al., 2006; Walsh et al., 2008). Attitudinal loyalty refers to customers' willingness to build relationships with service providers, whereas behavioural loyalty refers to customers' repeated purchasing behaviours. Both kinds of loyalty indicate that customer satisfaction with products and services is crucial to a customer's decision to remain in a buying relationship with a business (Huang et al., 2009). Based on the above discussion, the following hypotheses are proposed:

\section{The effect of service convenience}

1423 
IMDS

110,9

1424
H1-1. The higher the level of service convenience experienced by customers (including decision-making, access, transaction, benefit, and post-benefit forms of convenience), the higher the level of customer satisfaction with the business.

H1-2. The higher the level of customer satisfaction, the greater the degree of customer loyalty towards the business.

The mediating effect of perceived service value on the relationship between service convenience and customer satisfaction

Along with the direct effect of service convenience on customer satisfaction, which has been empirically verified (Colwell et al., 2008), the mediating role of perceived service value in the relationship between service convenience and customer satisfaction should be considered, with perceived value as a key contributor to high levels of customer satisfaction (Cockrill et al., 2009; Roig et al., 2009). Perceived value has been defined as "the consumer's overall assessment of the utility of a product based on perceptions of what is received and what is given" (Zeithaml, 1988, p. 14). In other words, customers compare the benefits of the service received with the necessary sacrifice required to get the service (Lee et al., 2004). As Heinonen (2004) notes, many of the conceptualisations of perceived value involve quality as the benefit and price as the sacrifice. This interpretation emphasises value as a monetary conceptualisation (Sweeney and Soutar, 2001; Nasution and Mavondo, 2008). Price is an important factor in customer satisfaction because customers tend to think of price whenever they evaluate the value of an acquired product or service (Martín-Consuegra et al., 2007). As discussed by McDougall and Levesque's (2000), customers who perceive that they receive value for money are more satisfied than customers who do not perceive that they receive value for money (Zeithaml, 1988). Thus, the give-and-get exchange process (Zeithaml, 1988), in addition to the factor of quality, works as an antecedent to service value as it is explored in previous studies (Lee et al., 2004; Wang et al., 2009). For this investigation, service convenience represented the get benefit in the service delivery process relative to the necessary sacrifice required to pay for the services in terms of monetary valuation. That is, if customers feel that they are receiving the best monetary value for the level of service convenience provided by a business, their positive perceptions of service value drive various positive behaviours (Chan et al., 2007), including customer satisfaction and loyalty (Heskett et al., 1994; McDougall and Levesque, 2000; Wang et al., 2009). These positive behaviours are important in developing long-term customer relationships and increasing the customer's intention to repurchase (Patterson and Spreng, 1997). This argument suggests that perceived service value is a required mediating factor in the relationship between service convenience and customer satisfaction, which would, in turn, influence customer loyalty toward a business (as discussed above).

While a direct link exists between service convenience and customer satisfaction, further study is needed to investigate whether varying degrees of perceived service value influence the convenience to satisfaction relationship (Colwell et al., 2008). Thus, based on the above discussion, this study assumes that there is a significant mediating effect of customer-perceived service value in the relationship between service convenience and customer satisfaction. Hence, the following hypothesis emerges:

H2. The customer-perceived service value of a business mediates the relationship between service convenience and customer satisfaction. 
The moderating effect of perceived service guarantee strength on the relationship between service convenience and customer satisfaction

Service convenience is a means of providing added value to customers to decrease the time and effort that they must expend on a service, thereby providing a holistic experience instead of separate dimensions of customer service convenience (Colwell et al., 2008). Brown (1990) has suggested that the benefit of service convenience is a psychological dimension that aims to add to a customer's comfort by saving a customer's time and effort. Thus, customers have to be aware of the convenience benefits being offered by service providers as intangible benefits (Lovelock, 1994). The intangible nature of service convenience "makes consumers being unable to experience the service offering prior to purchase and even the consumers often cannot evaluate it even after consumption" (Levy, 1999, p. 214). Accordingly, one means of reducing customer-perceived risk associated with the service is to increase customers' expectations regarding the level of service and enhance customer purchase intentions by signalling the organisation's commitment to customers with a service guarantee (Wirtz, 1998). Service guarantees can be categorised into two basic forms: the unconditional guarantee and the specific guarantee (McDougall et al., 1998). In general, a service guarantee is defined as:

[...] a promise by a firm that will perform at a certain level, and, if that level is not meet, the firm also promises to compensate the customer in some way (Hays and Hill, 2001, p. 405).

This implies that if a customer is aware of the chosen business's guarantee that it will offer a high level of service, the customer may perceive a lower level of performance risk associated with that firm's service offerings (Tsaur and Wang, 2009). That is, customers look to the guarantee for assurance that a high level of service quality will be delivered on a consistent basis (Marmorstein et al., 2001).

A review of service guarantee-related studies reveals that most, if not all, service guarantees are seen as an effective tool for jump-starting quality improvements (Wirtz, 1998), which serve to increase expected service quality (Wirtz et al., 2000; Tsaur and Wang, 2009), and leading to enhanced consumer satisfaction (Tucci and Talaga, 1997). However, Hays and Hill (2006) argue that the service guarantee should not be represented with a "zero-one variable" indicating its presence or absence as an explicit written guarantee to customers. Instead, they write that:

[...] it is possible that a firm has a strong implicit service contract with its customers, maintains high internal standards, and provides its customers with a strong service guarantee without having an explicit written service guarantee (Hays and Hill, 2006, p. 754).

In particular, Wirtz et al. (2000) propose that some firms that take pride in their "outstanding" services do not provide distinct guarantees to customers. Although the guarantees are not explicitly stated, customers are still confident that they can count on the firm to do what is right. This confidence suggests that even when a firm offers no written service guarantee, customers will still perceive a high level of service guarantee strength due to clear service quality standards or meaningful compensation during the consumption process (Hays and Hill, 2006). Therefore, despite its intangible nature, service convenience can be transformed into a measurable expectation based on the level of service guarantee strength perceived by customers who are ensured satisfaction once they touch, feel, and experience the service offerings (Levy, 1999).

\section{The effect of service convenience}

1425 
IMDS

110,9

1426
Thus, the relationship between service convenience and customer satisfaction will be strongest when customers have a positive perception of service guarantee strength.

Accordingly, this study is interested in how customer-perceived service guarantee strength moderates the relationship between service convenience and customer behaviour. That is, different levels of service guarantee lead to differences in the relationship between service convenience and customer satisfaction. This leads to the third research hypothesis:

H3. Customer-perceived service guarantee strength has a significant moderating effect on the relationship between service convenience and customer satisfaction.

In summary, it is proposed that service convenience is related to customer behaviour, with perceived service value serving as a mediating variable and perceived service guarantee strength serving as a moderating variable. Accordingly, a service convenience causation model is shown in Figure 1.

\section{Research method}

Sample

This paper takes a chain restaurant as its focus due to the importance of the restaurant industry in the service sector. One domestic-brand Chinese dining chain (named ABC restaurant in this study for not commercial purposes), which operates 12 franchised branches in Taiwan, was invited to participate in this study. The rationale for choosing a chain restaurant was based on the fact that restaurants in the chain operated with similar management styles, such as the menus, price, and decorations. In particular, from the year of 2007, this chain restaurant, regarding its operation management, service quality, and customer satisfaction, has been awarded the prize of good service practice from the Ministry of Economic Affairs of Taiwan, which indicates its benchmarking role within the restaurant industry. Accordingly, the following concerns make $\mathrm{ABC}$ restaurant an ideal target sample for exploring the research questions of this study.
Figure 1.

The research framework

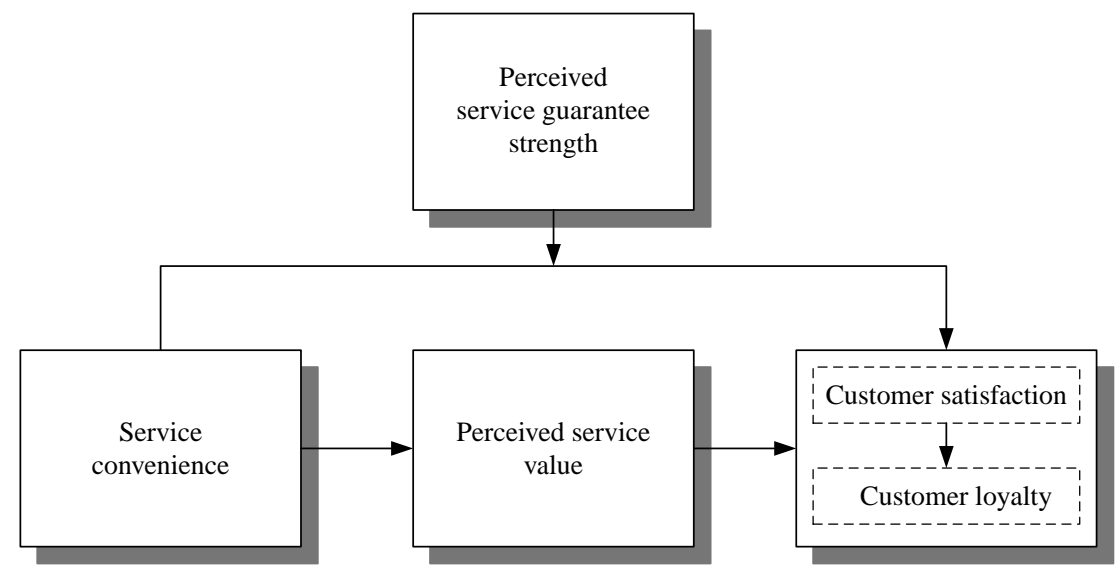


$\mathrm{ABC}$ restaurant's outstanding service quality indicates its role as the standard among the chain restaurants in Taiwan. Thus, it makes sense to further explore whether a service convenience-related casual relationship is present in this chain restaurant. Moreover, it must be noted that $\mathrm{ABC}$ restaurant is among those businesses that have not provided explicit service guarantee statements to their customers; they do not have a set of two-phase promises (i.e. service commitments associated with service compensation) as would constitute a service guarantee (Hays and Hill, 2006). That is, ABC restaurant was chosen as the sample firm in this study based on its high level of service quality and lack of explicit service guarantee statements.

\section{Measurements}

The items (listed in Appendix, Table AI) used to measure each variable were measured on a seven-point Likert scale, ranging from 1 - strongly disagree to 7 - strongly agree. The aspect of service convenience was modified from past research (Berry et al., 2002; Colwell et al., 2008) and included 15 items measuring the effectiveness of five types of service convenience provided by the restaurants. The aspect of perceived service guarantee strength was designed using past research (Hays and Hill, 2006) and included six items. The aspect of perceived service value was modified from past research (Lee et al., 2004) and included six items. The aspect of customer satisfaction was designed using past research (Cronin et al., 2000; Olorunniwo et al., 2006) and included five items. The aspect of customer's attitudinal and behavioural loyalty towards the restaurant was modified from past research (Reich et al., 2006) and included five items. Lastly, the respondents' demographic information was collected using six items (via a categorical scale) that included gender, age, educational level, monthly income, residency, and reason for dining.

\section{Sampling procedure}

This study attempts to explore the post-dining behaviours of customers as they relate to a set of service convenience-based causation relationships in selected $\mathrm{ABC}$ restaurants (a chain of Chinese restaurants). Following Chen and Tsai (2007), the survey instrument was first revised and finalised based on the feedback from three hospitality experts. Then, a pilot sample of 60 EMBA students who had eaten at one of the given chain restaurants was invited to join this study. Nine invalid questionnaires were eliminated, and 51 questionnaires were retained for analysis. In terms of the scale reliability, the results of the pilot test indicated that the survey instrument was reliable, with values for service convenience (Cronbach's $\alpha=0.956$ ), perceived service value (Cronbach's $\alpha=0.916$ ), perceived service guarantee strength (Cronbach's $\alpha=0.954$ ), customer satisfaction (Cronbach's $\alpha=0.909$ ), and customer loyalty (Cronbach's $\alpha=0.927$ ) all acceptable. Hence, the reliability of the survey instrument was deemed adequate.

As for the formal investigation, four branches of the $\mathrm{ABC}$ restaurant chain located in the Taipei area were selected not only for their increasing "sample representativeness" (Kerlinger and Lee, 2000) but also because the geographic location of the restaurants is an important concern (Huang, 2003). This setup, including all the branches of $\mathrm{ABC}$ restaurant located in the same area, was intended to increase our understanding of service convenience issues in the restaurant sector and allowed this study to draw more confident conclusions regarding service issues. Furthermore, permission to distribute the survey, offered by restaurateurs and managers, was obtained prior to the distribution of questionnaires to restaurant customers.

\section{The effect of service convenience}

1427 
IMDS 110,9

1428
Before the start of the investigation, eight postgraduate students were trained as interviewers so that they fully understood the content of the questionnaire and could answer any questions the respondents might have. Since four branches of ABC restaurant participated in this study, four groups composed of two interviewers each were given ID badges, and each group was assigned to one restaurant, allowing for a simultaneous study of all four branches. Data were collected at the four branches over a two-week period at different time intervals (i.e. on weekdays or weekends from 11:00 a.m. to 3:00 p.m. and from 5:00 to 9:00 p.m.) because there were more customers at these two peak times. The questionnaire was distributed to restaurant customers after their meals, which ensured that more accurate responses would be obtained (Kim et al., 2003). The purpose of the study was explained to the customers, and they were informed that if they were willing to participate in the survey and completed the questionnaire, they were thanked for their participation with a small gift (eco-chopsticks). To make the sample as representative of the target population as possible, the chosen respondents were customers 18 years of age and older, and an intercept approach was used, as suggested by Weiss et al. (2005). Each customer filled out a questionnaire anonymously and put it into an envelope to be left on a restaurant table or returned to a restaurant employee. Finally, a total of 600 respondents participated in this study.

\section{Data analysis and results}

Descriptive analysis

A statistical analysis of the collected questionnaires was computed based on the 498 usable responses from the four branches of $\mathrm{ABC}$ restaurant. The response rate is 83 per cent. SPSS 10.0 and AMOS 6.0 statistical software was used to conduct the following empirical analyses.

Of these 498 questionnaires, 41.4 per cent of the responses were from male respondents, while 58.6 per cent were from females. A substantial majority of the respondents were below 45 years of age but over 25 (62.4 per cent). The largest number of respondents (74.2 per cent) had at least a university degree (bachelor's or equivalent), and many respondents had an income of between NT\$20,000 and NT\$50,000[1] per month (48.6 per cent). Finally, the majority were from Northern Taiwan (92.4 per cent). In addition, regarding the guests' dining purposes, the results indicated that dining with family members $(308 / 704=43.8$ per cent) was the most popular, followed by dining with friends $(191 / 704=27.1$ per cent), with colleagues $(87 / 704=12.4$ per cent $)$, and trying new food $(62 / 704=8.8$ per cent). The detailed demographic profile is shown in Table I.

\section{Reliability and validity analysis}

The evaluation process began by initially performing all the 37 items at univariate level for normality by examining whether their absolute values of skew less than three and that of kurtosis less than four (Kline, 1998). The results (Table II) show that the absolute values of skew and those for kurtosis for all the items met the assumption for normality.

Next, the Cronbach's alpha values for each measure (range between 0.914 and 0.977) exceeded 0.7 (Nunnally, 1978), indicating that the measures had high reliability. In addition, composite reliability estimates exceeded the critical value of 0.7 recommended by Hair et al. (1998), indicating that it was satisfactory (Table II).

Furthermore, Tables II and III demonstrate that both the convergent and discriminant validity were supported. However, the correlation matrix (Table III) indicates that although none of the coefficients was greater than 0.9 (Hair et al., 1998), 


\begin{tabular}{|c|c|c|c|}
\hline Variables & Frequency(s) & Total (\%) & of service \\
\hline \multicolumn{3}{|l|}{ Gender } & \multirow{3}{*}{$\begin{array}{l}\text { of service } \\
\text { convenience }\end{array}$} \\
\hline Male & 206 & 41.4 & \\
\hline Female & 292 & 58.6 & \\
\hline \multicolumn{4}{|l|}{ Age } \\
\hline $18-24$ & 64 & 12.9 & \multirow{2}{*}{1429} \\
\hline 25-34 & 158 & 31.7 & \\
\hline $35-44$ & 153 & 30.7 & \\
\hline $45-54$ & 94 & 18.9 & \\
\hline 55 and over & 29 & 5.8 & \\
\hline \multicolumn{4}{|l|}{ Education level } \\
\hline Primary & 22 & 4.4 & \\
\hline High school & 106 & 21.3 & \\
\hline University & 308 & 61.8 & \\
\hline Postgraduate & 62 & 12.4 & \\
\hline \multicolumn{4}{|l|}{ Monthly income (NT\$) } \\
\hline Under 20,000 & 40 & 8.0 & \\
\hline $20,001-30,000$ & 87 & 17.5 & \\
\hline $30,001-40,000$ & 95 & 19.1 & \\
\hline $40,001-50,000$ & 60 & 12.0 & \\
\hline $50,001-60,000$ & 57 & 11.4 & \\
\hline $60,001-70,000$ & 36 & 7.2 & \\
\hline Over 70,001 & 65 & 13.1 & \\
\hline Other (unemployed) & 58 & 11.6 & \\
\hline \multicolumn{4}{|l|}{ Residency } \\
\hline North & 460 & 92.4 & \\
\hline Middle & 12 & 2.4 & \\
\hline South & 13 & 2.6 & \\
\hline East & 7 & 1.4 & \\
\hline Other (overseas) & 6 & 1.2 & \\
\hline \multicolumn{4}{|c|}{ Dining purpose (multiple-choice) } \\
\hline Dinning with family & 308 & 43.8 & \\
\hline Dinning with friends & 191 & 27.1 & \\
\hline Dinning with colleagues & 87 & 12.4 & \\
\hline Celebrating special events & 35 & 5.0 & \\
\hline Try new food & 62 & 8.8 & \\
\hline Other & 21 & 3.0 & \\
\hline \multicolumn{3}{|l|}{ Note: $n=498$} & Profile of respondents \\
\hline
\end{tabular}

the service convenience-related factors remained collinear, which likely reduced overall structural equation modelling (SEM) model fit. This phenomenon also occurred in Featherman and Pavlou's (2003) research in which the performance-related risk facets remained as higher correlation coefficients than other constructs in the model. Nevertheless, as shown in Table II, the values of the average variance extracted (AVE) were greater than 50 per cent, which supports the convergent validity (Fornell and Larcker, 1981). In addition, the discriminant validity was considered reliable in Table III, which demonstrates that the square root of the AVE of each construct should generally be higher than the correlations between it and any other constructs in the model (Fornell and Larcker, 1981). 


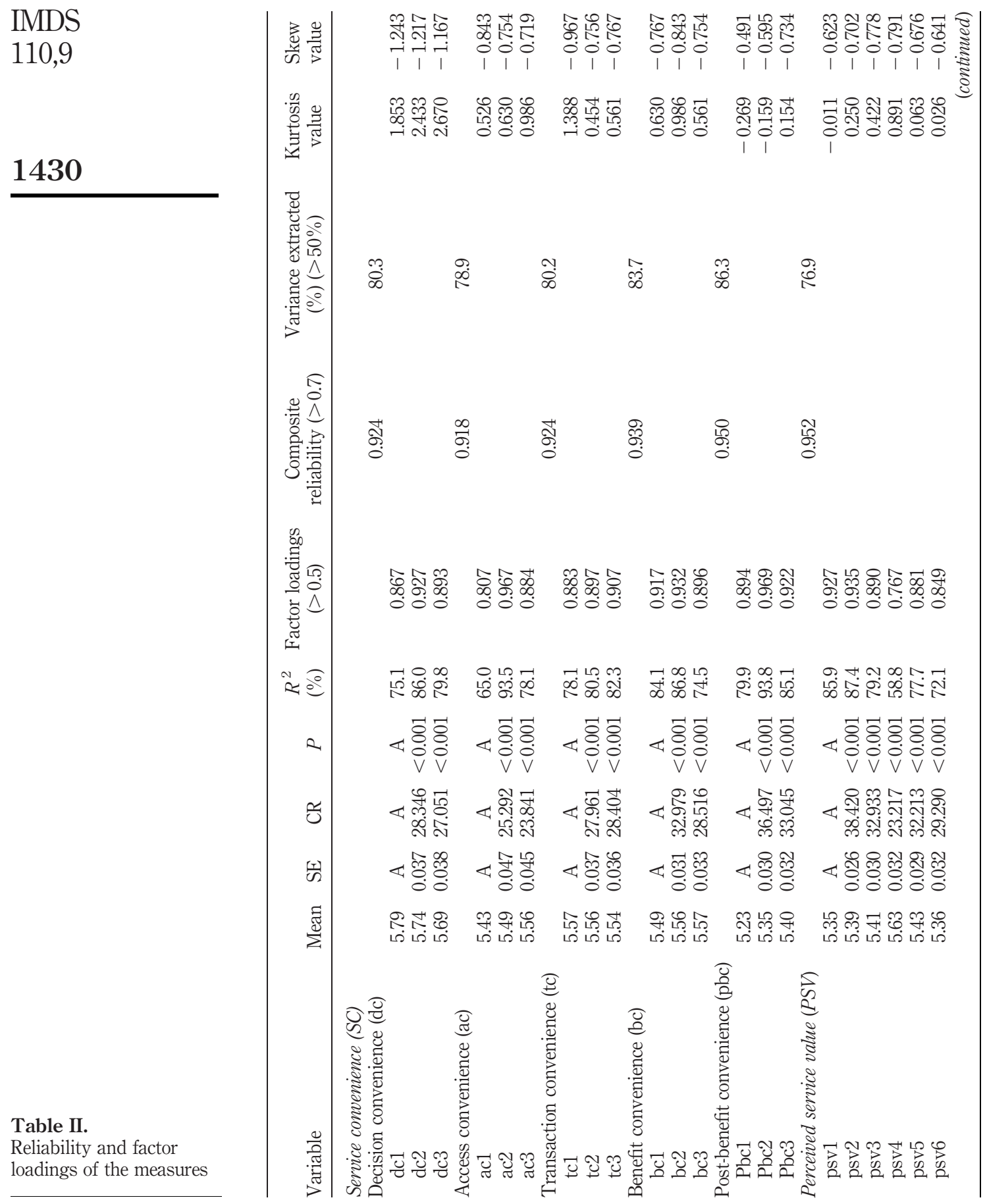




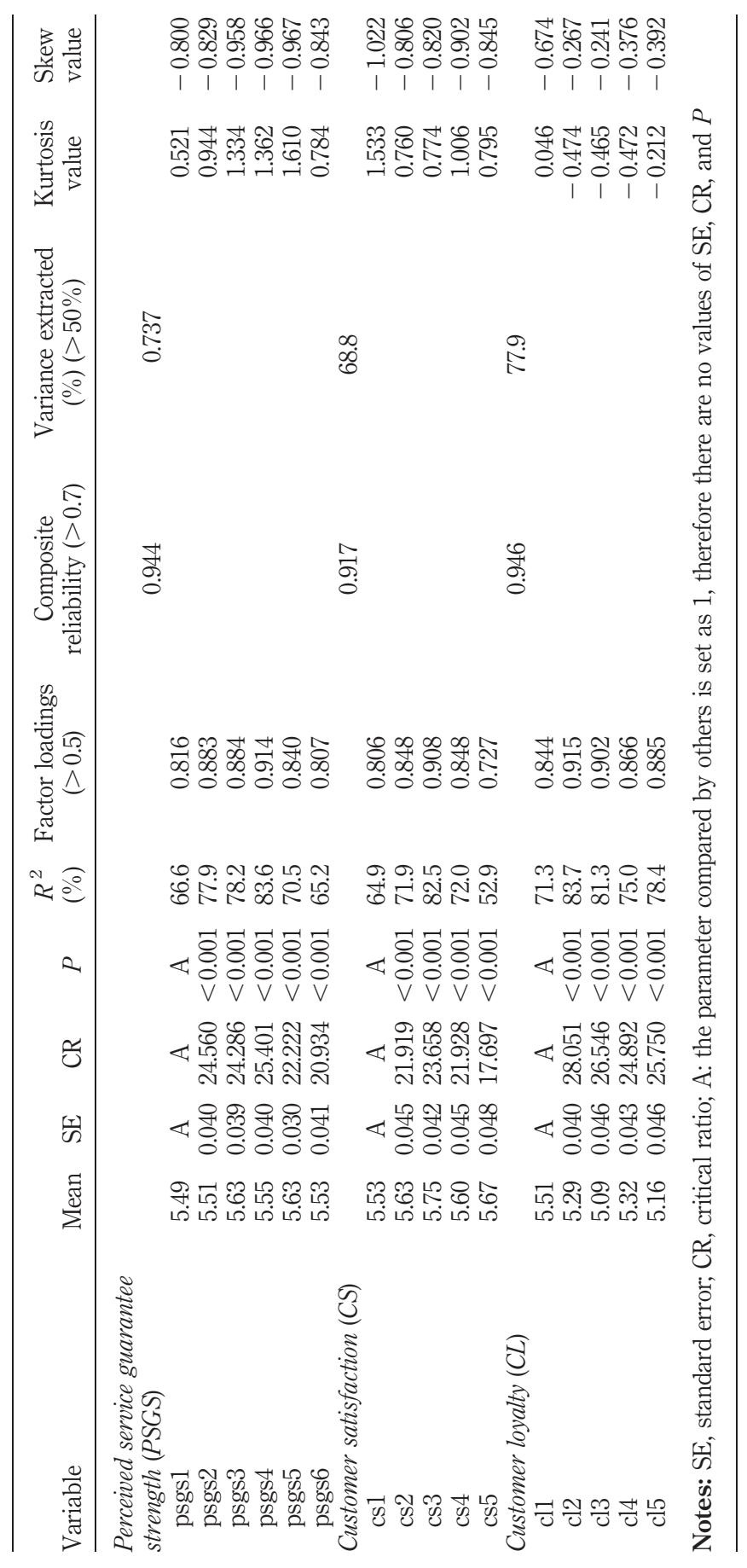

The effect of service convenience

1431

Table II. 


\section{IMDS \\ 110,9}

1432

Table III.

Correlation matrix

\begin{tabular}{lccccccccr}
\hline & 1 & 2 & 3 & 4 & 5 & 6 & 7 & 8 & 9 \\
\hline 1. dc & 0.896 & & & & & & & & \\
2. ac & 0.812 & 0.888 & & & & & & & \\
3. tc & 0.795 & 0.883 & 0.896 & & & & & & \\
4. bc & 0.807 & 0.859 & 0.839 & 0.915 & & & & & \\
5. pbc & 0.669 & 0.808 & 0.830 & 0.816 & 0.929 & & & & \\
6. PSV & 0.481 & 0.500 & 0.492 & 0.497 & 0.501 & 0.877 & & & \\
7. PSGS & 0.772 & 0.711 & 0.678 & 0.699 & 0.578 & 0.477 & 0.858 & & \\
8. CS & 0.526 & 0.544 & 0.552 & 0.548 & 0.484 & 0.751 & 0.555 & 0.829 & \\
9. CL & 0.412 & 0.429 & 0.434 & 0.438 & 0.396 & 0.532 & 0.413 & 0.508 & 0.882
\end{tabular}

Notes: All correlations significant at: $p<0.01$; the square root of AVE displayed in the diagonal

\section{Structural model}

The structural model testing was conducted with path analysis by using AMOS 6.0. All constructs (i.e. service convenience, perceived service guarantee strength, perceived service value, customer satisfaction, and customer loyalty) discussed above were included in the model, as shown in Figure 2.

Regarding the model fit, even though the $\chi^{2}$ statistics was too high due to the large sample size (Bagozzi and Yi, 1988) and some statistics (such as GFI) marginally approach the required statistics, the results, as listed in Table IV, indicate that the SEM statistics, such as AGFI (0.839), NFI (0.930), CFI (0.950), RMSEA (0.069), and CMIN/DF (3.357) sampled from restaurant customers, match the suggested requirement for the model's goodness of fit.

Figure 2.

Results of structural modelling analysis

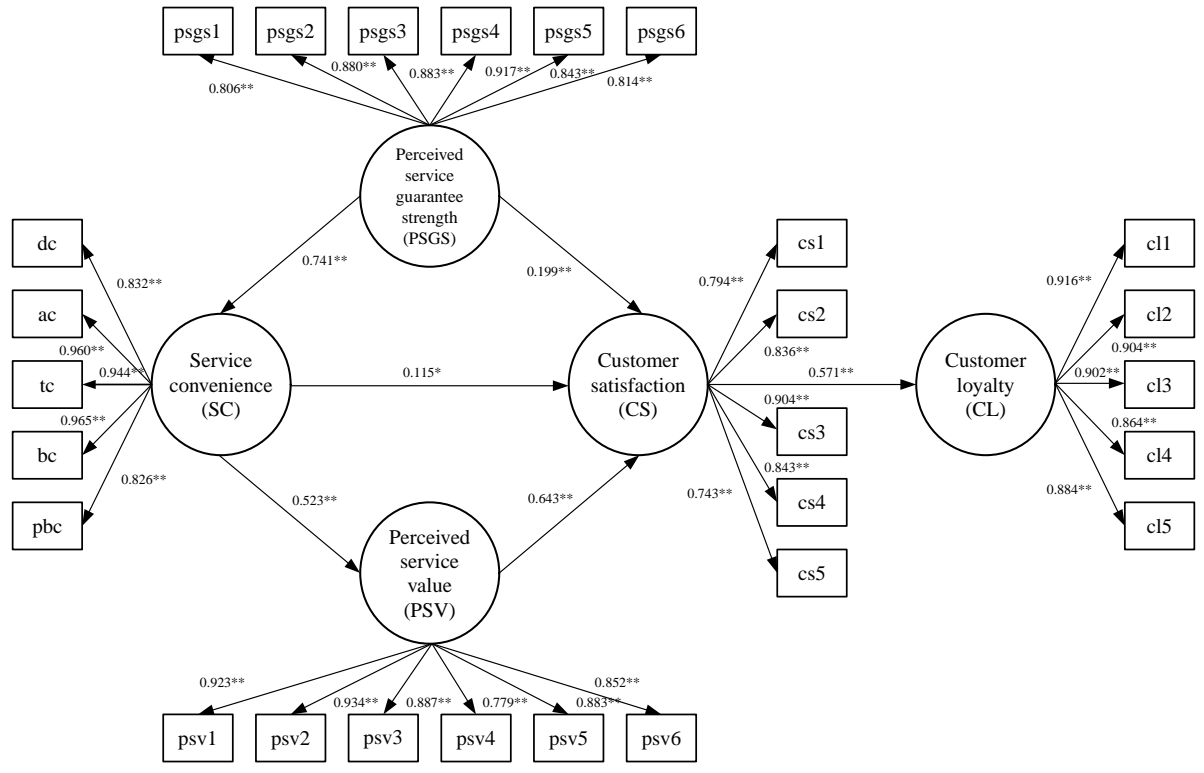

Note: Significance at: $* p<0.05$ and $* * p<0.001$ 
Test of hypotheses

Hypotheses 1-1 and 1-2. According to the path analysis from Amos (as shown in Figure 2), the results regarding direct effects among the constructs indicate that H1-1 $(\beta=0.115, p<0.05)$ and $H 1-2(\beta=0.571, p<0.001)$ are supported. Thus, service convenience has a positive impact on customer satisfaction, and customer satisfaction has a positive impact on customer loyalty.

Hypothesis 2. Regarding the indirect effects, the results support $H 2$, in which perceived service value works as a mediator of service convenience and customer satisfaction. That is, the indirect effect of service convenience through perceived service value and customer satisfaction is greater $(\beta=0.336)$ than the direct effect of service convenience on customer loyalty $(\beta=0.115)$. In addition, based on the aforementioned statistically significant results of the path analysis, the hierarchical effect of service convenience on post-dining behaviours was investigated, i.e. the indirect effect of service convenience on customer loyalty $(\mathrm{SC} \rightarrow \mathrm{PSV} \rightarrow \mathrm{CS} \rightarrow \mathrm{CL}$ versus $\mathrm{SC} \rightarrow \mathrm{CS} \rightarrow \mathrm{CL}$ ) was examined. The results show that the indirect effect of service convenience through perceived service value and customer satisfaction on customer loyalty is greater $(0.523 \times 0.643 \times 0.571=0.192)$ than the indirect effect of service convenience through customer satisfaction alone on customer loyalty $(0.115 \times 0.571=0.066)$. Accordingly, the role of perceived service value is critical, as it specifically mediates the relationship between service convenience and customer satisfaction and influences customer loyalty.

Furthermore, because $H 2$ is supported, two conditions have been employed to test the extent of the mediating effect between the variables. In other words, after adding the mediator (i.e. perceived service value) to the prediction of the dependent variable (i.e. customer satisfaction) based on the independent variable (i.e. service convenience) in the second regression, the effect of the service convenience's decreasing or reaching a figure close to zero comes to be of some concern. That is, a partial or complete mediation effect can be clarified using this method (Baron and Kenny, 1986). Table V lists the information on the partial mediating effects of perceived service value between service convenience and customer satisfaction.

Hypothesis 3. An additional evaluation of the model indicates that perceived service guarantee strength has a significant impact on service convenience $(\beta=0.74$, $p<0.001)$ and customer satisfaction $(\beta=0.20, p<0.001)$, as shown in Figure 2 . The objective of this section is to examine if customer-perceived service guarantee strength will moderate the relationship between service convenience and customer satisfaction. The regression results (as shown in Table VI) indicate that the interaction between perceived service guarantee strength and service convenience has a significant effect on customer satisfaction $(\beta=0.45, p<0.05)$.

\begin{tabular}{llr}
\hline Fit indices & Recommended value & Results \\
\hline Goodness-of-fit index (GFI) & $>0.90$ (Hu and Bentler, 1999) & 0.864 \\
Adjusted goodness-of-fit index (AGFI) & $>0.80$ (Scott, 1994) & 0.839 \\
Normalised fit index (NF) & $>0.90$ (Hu and Bentler, 1999) & 0.930 \\
Comparative fit index (CFI) & $>0.90$ (Hu and Bentler, 1999) & 0.950 \\
Root mean square error of approximation (RMSEA) & $<0.08$ (Hair et al., 1998) & 0.069 \\
Chi-square/degrees freedom ( $\left.\chi^{2} / \mathrm{df}\right)$ & $<5.00$ (Loo and Thorpe, 2000) & 3.357
\end{tabular}

The effect of service convenience

1433 
IMDS

110,9

1434

Furthermore, to test how the different levels of customer-perceived service guarantee strength influence the relationship between service convenience and customer satisfaction, the data on perceived service guarantee strength and service convenience were divided into high and low groups based on their mean scores $(\bar{x}=5.532$ for service convenience; $\bar{x}=5.557$ for perceived service guarantee strength). Then, these groups were crossed, and four alignments were obtained as shown in Table IV. The first group displays high-perceived service guarantee strength and high service convenience $(n=229)$; the second group displays high-perceived service guarantee strength but low service convenience $(n=56)$; the third group displays low-perceived service guarantee strength and high service convenience $(n=54)$; and, finally, the fourth group displays low-perceived service guarantee strength and low service convenience $(n=159)$.

The results of the ANOVA analysis and Duncan post-hoc test are shown in Table VII; the $F$-values and $p$-values are all significant $(F=57.341, p<0.001)$. According to the results of the Duncan post-hoc test, the customer satisfaction of the first group is higher than that of the other three groups, whereas there is no significant difference between the customer satisfaction levels of the second and the third group. Furthermore, as shown in Figure 3, when customer-perceived service guarantee strength

Table V.

Regression results for the mediating effect of perceived service value

\begin{tabular}{|c|c|c|c|c|c|c|c|c|}
\hline Mediating effect & Model 1 & $\beta$ & $\mathrm{SE}$ & Sig. & Model 2 & $\beta$ & $\mathrm{SE}$ & Sig. \\
\hline \multirow[t]{5}{*}{$\mathrm{SC} \rightarrow \mathrm{PSV} \rightarrow \mathrm{CS}$} & Constant & 2.879 & 0.181 & 0.000 & Constant & 1.618 & 0.155 & 0.000 \\
\hline & $\mathrm{SC}$ (CS as the DV) & 0.499 & 0.032 & 0.000 & $\mathrm{SC}$ & 0.208 & 0.029 & 0.0 \\
\hline & & & & & $\begin{array}{l}\text { PSV } \\
\text { (CS as the DV) }\end{array}$ & 0.528 & 0.028 & 0.0 \\
\hline & $R^{2}$ & 0.325 & & & $R^{2}$ Adiusted $R^{2}$ & 0.777 & & \\
\hline & $F$ & 238.537 & & 0.000 & & 377.600 & & 0.000 \\
\hline
\end{tabular}

Notes: SC, service convenience; CS, customer satisfaction; PSV, perceived service value; DV, dependent variable; SE, standard error; sig., significance; $\beta$ and SE are unstandardised coefficients
Table VI.

Regression results for the moderating effect of perceived service guarantee strength
The effect of service convenience on customer satisfaction (CS)

Moderating effect Model 1

Model 2

\begin{tabular}{|c|c|c|c|}
\hline PSGS & Independent variable & & \\
\hline$\downarrow$ & Service convenience (SC) & $0.352 *$ & 0.102 \\
\hline $\mathrm{SC} \rightarrow \mathrm{CS}$ & Moderator & & \\
\hline & Perceived service guarantee strength (PSGS) & $0.296^{*}$ & 0.070 \\
\hline & $\begin{array}{l}\text { Interaction term } \\
\mathrm{SC} \times \mathrm{PSGS}\end{array}$ & & $0.450 * *$ \\
\hline & Model F & 142.156 & 4.667 \\
\hline & $R^{2}$ & $0.365 *$ & $0.371^{* *}$ \\
\hline & Adjusted $R^{2}$ & $0.362^{*}$ & $0.367^{* *}$ \\
\hline & $R^{2}$ change & & $0.006^{* *}$ \\
\hline
\end{tabular}

Note: Significance at: ${ }^{*} p<0.001$ and ${ }^{* *} p<0.05$ 


\begin{tabular}{|c|c|c|c|c|c|c|}
\hline & \multicolumn{2}{|c|}{$\begin{array}{c}\text { High perceived service guarantee } \\
\text { strength }\end{array}$} & \multicolumn{2}{|c|}{$\begin{array}{c}\text { Low perceived service guarantee } \\
\text { strength }\end{array}$} & \multirow[b]{2}{*}{$\begin{array}{l}\text { Duncan } \\
\text { post hoc }\end{array}$} & of service \\
\hline & $\begin{array}{l}\text { High service } \\
\text { convenience }\end{array}$ & $\begin{array}{l}\text { Low service } \\
\text { convenience }\end{array}$ & $\begin{array}{l}\text { High service } \\
\text { convenience }\end{array}$ & $\begin{array}{l}\text { Low service } \\
\text { convenience }\end{array}$ & & convenience \\
\hline $\begin{array}{l}\text { Customer } \\
\text { satisfaction }\end{array}$ & $\begin{array}{l}\text { The 1st group } \\
6.059\end{array}$ & $\begin{array}{l}\text { The 2nd group } \\
5.657\end{array}$ & $\begin{array}{l}\text { The 3rd group } \\
5.600\end{array}$ & $\begin{array}{l}\text { The 4th group } \\
5.037\end{array}$ & \multirow{2}{*}{$\begin{array}{l}1>2 \\
1>3 \\
1>4 \\
2=3>4\end{array}$} & 1435 \\
\hline $\begin{array}{l}F \\
P\end{array}$ & $\begin{array}{c}57.341 \\
0.000 *\end{array}$ & & & & & \\
\hline \multicolumn{6}{|c|}{ Note: Significant at: ${ }^{*} p<0.001$} & ANOVA \\
\hline
\end{tabular}

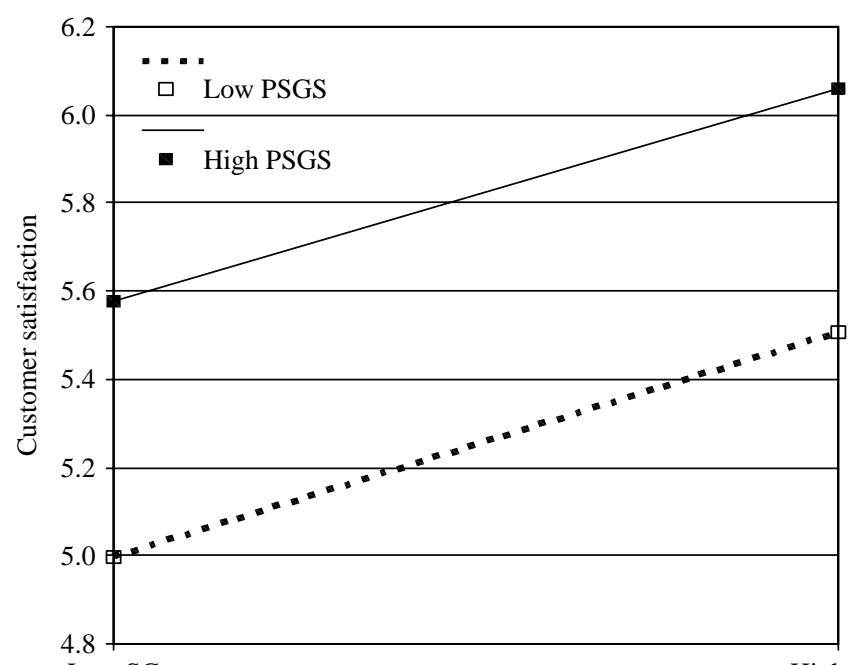

Low SC

High SC

Service convenience (SC)
Figure 3.

The moderating effect of perceived service guarantee strength (PSGS)

is low, high service convenience will entail lower customer satisfaction than does low service convenience coupled with a high level of perceived service guarantee strength. Thus, $H 3$ is supported: a customer's perception of a firm's service guarantee strength has a significant impact on the relationship between service convenience and customer satisfaction.

\section{Conclusions and managerial implications}

The study contributes to a conceptual model that, reflecting the mediating role of customer-perceived service value and the moderating role of customer-perceived service guarantee strength, indicates the effect of service convenience on customers' post-purchasing behaviours (i.e. customer satisfaction and loyalty). Therefore, the service convenience-related constructs combine to offer restaurant managers important information about managing and improving service quality in their restaurants. 
IMDS

110,9

1436

First, regarding the relationship between service convenience and customer satisfaction, the results are in line with Colwell et al.'s (2008) findings that service convenience has a positive effect on customer satisfaction. Based on the results, it would seem that restaurant managers should ensure that customers can easily and quickly access the benefits of the services they are seeking to obtain. Berry et al. (2002) have proposed that customers' perceptions of service convenience influence their perceptions of service quality and satisfaction. To put it simply, when customers can easily and conveniently experience the benefits of a restaurant's services, they are more likely to be satisfied with that restaurant. Following this pattern, another important finding is that customer satisfaction directly influences customer loyalty toward a restaurant. That is, as concluded by Kim et al. (2007), attitudinal and behavioural aspects should be considered in measuring the "true" concept of loyalty. Specifically, customer satisfaction does not guarantee customer repeat purchasing behaviour, which should pass through the phase of attitudinal and behavioural conformity towards the restaurant.

Second, regarding the role of perceived service value, the empirical results clarify that perceived service value works as a mediating variable in the relationship between service convenience and customer satisfaction. That is, service convenience will positively influence customer satisfaction, and this relationship will be strengthened through customer-perceived service value as it relates to the service offerings. This implies that the value that a restaurant offers its customers in relation to the price asked must truly reflect a successful give and receive exchange (Zeithaml, 1988; Lee et al., 2004). Specifically, as claimed by Ryu et al. (2008), price is one of the important tangible cues that can enhance a restaurant's image and influence customers' perceived value of the restaurant. In other words, value for money is an important attribute that helps customers evaluate service quality in the food service industry (Chow et al., 2007). From a managerial perspective, a firm should focus more on delivering the right quality of service at the right price and treating the customers fairly rather than focusing on competitor's prices (Martín-Consuegra et al., 2007). In particular, chain restaurant management should give this phenomenon special consideration because the chain's brand identity is established based on the consistent value that customers receive at each branch.

Third, the findings of the present paper complement the extant literature by demonstrating that customer-perceived service guarantee strength has a significant moderating effect on the service convenience-customer satisfaction relationship. For instance, the results indicate that when restaurants offer acceptable service convenience and emphasise the improvement of customer-perceived service guarantee strength, they will enjoy higher customer satisfaction than will occur when they offer a higher level of service convenience but demonstrate low-perceived service guarantee strength. The findings also yield managerial insights that restaurants can use to save customers time and effort when they are dining at a restaurant, including offering an acceptable level of service convenience and improving the quality of the services. The result of these improvements will be an increase in customer-perceived service guarantee strength and, therefore, an increase in customer satisfaction or even loyalty to the restaurant. In sum, when customers' perceptions of provided service guarantee strength is high, they are more likely to experience satisfaction because they will feel more conscious of the benefits associated with the services (i.e. service convenience). Hence, it is critical for restaurants to actively manage and supervise the quality of their service 
offerings and the process of service delivery to make customers feel as confident in their service offerings as possible, thereby earning customers' trust.

\section{Limitations and directions for further research}

The limitations of this research provide direction for future study. First, as discussed by Kim et al. (2007), because loyal customers and frequent visitors are significantly different, future researchers should note and distinguish between their perceptions regarding service convenience, perceived service value, and perceived service guarantee strength as linked to post-purchasing behaviours. Second, this study did not research how perceived service value works as a moderator of the effect of the relationship between customer satisfaction and loyalty (Chang et al., 2009). This limited understanding of the relationships among service convenience, customer satisfaction, and loyalty would be interesting to consider in future research. Third, the findings of this study should not be generalised because the sample used in this study was limited to domestic-brand restaurants located in the same geographic location. Replication studies should be done in different areas using various restaurant segments (e.g. foreign-brand restaurants) to compare and validate the results of this research. Finally, the use of some socioeconomic variables could shed further light on how customers react to aspects of restaurant service offerings such as service convenience, as discussed in the paper. For example, Kim et al. (2003) have found that gender, average spending, and different dining occasions differently impact perceptions of service quality. Therefore, future research should consider how restaurant service convenience, service value, and service guarantee strength, as perceived by customers, might significantly differ based on demographic characteristics such as education, income, and profession.

\section{Note}

1. NT $\$ \leftrightharpoons 0.33$ US $\$$ at the time of study.

\section{References}

Bagozzi, R.P. and Yi, Y. (1988), "On the evaluation of structural equation models", Journal of the Academy of Marketing Science, Vol. 16 No. 1, pp. 74-94.

Baron, R.M. and Kenny, D.A. (1986), "The moderator-mediator variable distinction in social psychological research: conceptual, strategic, and statistical considerations", Journal of Personality and Social Psychology, Vol. 51 No. 6, pp. 1173-82.

Bearden, W.O. and Teel, J.E. (1983), "Selected determinants of customer satisfaction and complaint reports", Journal of Marketing Research, Vol. 20 No. 1, pp. 21-8.

Berry, L.L., Seiders, K. and Grewal, D. (2002), "Understanding service convenience”, Journal of Marketing, Vol. 66 No. 3, pp. 1-17.

Brown, L.G. (1990), "Convenience in services marketing”, Journal of Services Marketing, Vol. 4 No. 1 , pp. 53-9.

Brunner, T.A., Stocklin, M. and Opwis, K. (2008), "Satisfaction, image and loyalty: new versus experienced customers", European Journal of Marketing, Vol. 42 Nos 9/10, pp. 1095-105.

Chan, H., Wan, L.C. and Sin, L.Y.M. (2007), "Hospitality service failures: who will be more dissatisfied”, International Journal of Hospitality Management, Vol. 26 No. 3, pp. 531-45.

Chang, H.H., Wang, Y.H. and Yang, W.Y. (2009), "The impact of e-service quality, customer satisfaction and loyalty on e-marketing: moderating effect of perceived value", Total Quality Management \& Business Excellence, Vol. 20 No. 4, pp. 423-43.

\section{The effect of service convenience}

1437 
IMDS

110,9

\section{8}

Chen, C.F. and Tsai, D.C. (2007), "How destination image and evaluative factors affect behavioral intentions?", Tourism Management, Vol. 28 No. 4, pp. 1115-22.

Chen, S.C., Chen, H.H. and Chen, M.F. (2009), "Determinants of satisfaction and continuance intention towards self-service technologies", Industrial Management \& Data Systems, Vol. 109 No. 9, pp. 1248-63.

Chow, I.H.S., Lau, V.P., Lo, T.W.C., Sha, Z. and Yun, H. (2007), "Service quality in restaurant operations in China: decision and experiential-oriented perspectives", International Journal of Hospitality Management, Vol. 26 No. 3, pp. 698-710.

Cockrill, A., Goode, M.M.H. and Beetles, A. (2009), "The critical role of perceived risk and trust in determining customer satisfaction with automated banking channels", Services Marketing Quarterly, Vol. 30 No. 2, pp. 174-93.

Colwell, S.R., Aung, M., Kanetkar, V. and Holden, A.L. (2008), "Toward a measure of service convenience: multiple-item scale development and empirical test", Journal of Services Marketing, Vol. 22 No. 2, pp. 160-9.

Cronin, J.J., Brady, M.K. and Hult, G.T.M. (2000), "Assessing the effects of quality, value, and customer satisfaction on consumer behavioral intentions in service environments", Journal of Retailing, Vol. 76 No. 2, pp. 193-218.

Eggert, A. and Ulaga, W. (2002), "Customer perceived value: a substitute for satisfaction in business markets?”, Journal of Business \& Industrial Marketing, Vol. 17 Nos 2/3, pp. 107-18.

Featherman, M.S. and Pavlou, P.A. (2003), "Predicting e-service adoption: a perceived risk facets perspective", International Journal of Human-Computer Studies, Vol. 59 No. 4, pp. 451-74.

Fornell, C. and Larcker, D.F. (1981), "Evaluating structural equation models with unobservable variables and measurement error", Journal of Marketing Research, Vol. 18 No. 1, pp. 39-50.

Fornell, C., Johnson, M.D., Anderson, E.W., Cha, J. and Bryant, B.E. (1996), "The American customer satisfaction index: nature, purpose and findings", Journal of Marketing, Vol. 60 No. 4, pp. 7-18.

Garbarino, E. and Johnson, M.S. (1999), "The different roles of satisfaction, trust, and commitment in consumer relationships", Journal of Marketing, Vol. 63 No. 2, pp. 70-87.

Hair, J.F., Anderson, R.E., Taltam, R.L. and Black, W.C. (1998), Multivariate Data System with Readings, 5th ed., Prentice-Hall, Englewood Cliffs, NJ.

Hays, J.M. and Hill, A.V. (2001), "A longitudinal study of the effect of a service guarantee on service quality", Production and Operations Management, Vol. 10 No. 4, pp. 405-23.

Hays, J.M. and Hill, A.V. (2006), "Service guarantee strength: the key to service quality", Journal of Operations Management, Vol. 24 No. 6, pp. 753-64.

He, Y. and Song, H. (2009), "A mediation model of tourists' repurchase intentions for packaged tour services”, Journal of Travel Research, Vol. 47 No. 3, pp. 317-31.

Heinonen, K. (2004), "Reconceptualizing customer perceived value: the value of time and place", Managing Service Quality, Vol. 14 Nos 2/3, pp. 205-15.

Heskett, J.L., Jones, T.O., Loveman, G.W., Sasser, W.E. and Schlesinger, L.A. (1994), "Putting the service-profit chain to work", Harvard Business Review, Vol. 72 No. 2, pp. 164-74.

Hu, L. and Bentler, P.M. (1999), "Cutoff criteria for fit indices in covariance structure analysis: conventional criteria versus new alternatives", Structural Equation Modeling, Vol. 6 No. 1, pp. 1-55.

Huang, C.H. (2003), "A comparison of the service quality perspectives between restaurant customers and restaurateurs in Taiwan”, Journal of Foodservice Business Research, Vol. 6 No. 2, pp. 87-104. 
Huang, Y., Huang, F., Hsu, M.K. and Chang, F. (2009), "Determinants and outcomes of relationship quality: an empirical investigation on the Chinese travel industry", Asia Pacific Journal of Tourism Research, Vol. 14 No. 1, pp. 59-75.

Keaveney, S. (1995), "Customer switching behavior in service industries: an exploratory study", Journal of Marketing, Vol. 59 No. 2, pp. 71-82.

Kerlinger, F.N. and Lee, H.B. (2000), Foundations of Behavioral Research, 4th ed., Harcourt College Publishers, Fort Worth, TX.

Kim, H.J., McCahon, C. and Miller, J. (2003), “Assessing service quality in Korean casual-dining restaurants using DINESERV”, Journal of Foodservice Business Research, Vol. 6 No. 1, pp. 67-86.

Kim, W.G., Lee, S. and Lee, H.Y. (2007), "Cobranding and brandy loyalty”, Journal of Quality Assurance in Hospitality \& Tourism, Vol. 8 No. 2, pp. 1-23.

Kline, R.B. (1998), Principles and Practice of Structural Equation Modeling, Guilford Press, New York, NY.

Kotler, P. and Armstrong, G. (2004), Principles of Marketing, Prentice-Hall, Upper Saddle River, NJ.

Lee, Y.K., Ahn, W.K. and Kim, K. (2008), "A study on the moderating role of alternative attractiveness in the relationship between relational benefits and customer loyalty", International Journal of Hospitality \& Tourism Administration, Vol. 9 No. 1, pp. 52-70.

Lee, Y.K., Lee, Y., Lee, K.A., Park, D.H. and Moon, H. (2004), "Exploring the role of service value in the relationship between service quality and customer satisfaction", International Journal of Hospitality \& Tourism Administration, Vol. 5 No. 1, pp. 67-86.

Lee, Y.K., Park, K.H., Park, D.H., Lee, K.A. and Kwon, Y.J. (2005), “The relative impact of service quality on service value, customer satisfaction and customer loyalty in Korean family restaurant context", International Journal of Hospitality \& Tourism Administration, Vol. 6 No. 1, pp. 27-51.

Levy, J.S. (1999), "Marketing service guarantees for health care”, Nursing Economics, Vol. 17 No. 4, pp. 214-8.

Liang, C.J. and Wang, W.H. (2006), "The behavioural sequence of the financial services industry in Taiwan: service quality, relationship quality and behavioural loyalty", The Service Industries Journal, Vol. 26 No. 2, pp. 119-45.

Loo, R. and Thorpe, K. (2000), "Confirmatory factor analyses of the full and short versions of the Marlowe-Crowne Social Desirablity Scale", The Journal of Social Psychology, Vol. 140 No. 5 , pp. 628-35.

Lovelock, C.H. (1994), Product Plus: How Product + Service $=$ Competitive Advantage, McGraw-Hill Press, New York, NY.

McDougall, G.H.G. and Levesque, T. (2000), "Customer satisfaction with services: putting perceived value into the equation", Journal of Services Marketing, Vol. 14 No. 5, pp. 392-410.

McDougall, G.H.G., Levesque, T. and VanderPlaat, P. (1998), "Designing the service guarantee: unconditional or specific?”, Journal of Services Marketing, Vol. 12 No. 4, pp. 278-93.

Marmorstein, H., Sarel, D. and Lassar, W.M. (2001), "Increasing the persuasiveness of a service guarantee: the role of service process evidence", Journal of Services Marketing, Vol. 15 No. 2, pp. 147-59.

Martín-Consuegra, D., Molina, A. and Esteban, A. (2007), "An integrated model of price, satisfaction and loyalty: an empirical analysis in the service sector", Journal of Product \& Brand Management, Vol. 16 No. 7, pp. 459-68.

Morganosky, M. (1986), "Cost-versus convenience-oriented consumers: demographic, lifestyle, and value perspectives”, Psychology \& Marketing, Vol. 3 No. 1, pp. 35-46.

\section{The effect of service convenience}

1439 
IMDS

110,9

1440
Nasution, H.N. and Mavondo, F.T. (2008), "Customer value in the hotel industry: what managers believe they deliver and what customer experience", International Journal of Hospitality Management, Vol. 27 No. 2, pp. 204-13.

Nunnally, J.C. (1978), Psychometric Theory, McGraw-Hill, New York, NY.

Oliver, R.L. (1980), "A cognitive model of the antecedents and consequences of satisfaction decisions", Journal of Marketing Research, Vol. 17 No. 4, pp. 460-9.

Oliver, R.L. (1993), "Cognitive, affective, and attribute bases of the satisfaction response", Journal of Consumer Research, Vol. 20 No. 3, pp. 418-30.

Oliver, R.L. (1997), Satisfaction: A Behavioral Perspective on the Consumer, McGraw-Hill, New York, NY.

Olorunniwo, F., Hsu, M.K. and Udo, G.F. (2006), "Service quality, customer satisfaction, and behavioral intentions in the service factory", Journal of Services Marketing, Vol. 20 No. 1, pp. 59-72.

Patterson, P. and Spreng, R. (1997), "Modelling the relationship between perceived value, satisfaction and repurchase intentions in a business-to-business, services context: an empirical examination", International Journal of Service Industry Management, Vol. 8 No. 5, pp. 414-34.

Reich, A.Z., McCleary, K.W., Tepanon, Y. and Weaver, P.A. (2006), "The impact of product and service quality on brand loyalty: an exploratory investigation of quick-service restaurants", Journal of Foodservice Business Research, Vol. 8 No. 3, pp. 35-53.

Roig, J.C.F., Garcia, J.S. and Tena, M.A.M. (2009), "Perceived value and customer loyalty in financial services”, The Services Industries Journal, Vol. 29 No. 6, pp. 775-89.

Roig, J.C.F., García, J.S., Tena, M.A.M. and Monzonis, J.L. (2006), "Customer perceived value in banking services”, International Journal of Bank Marketing, Vol. 24 No. 5, pp. 266-83.

Ryu, K., Han, H. and Kim, T.H. (2008), “The relationship among overall quick-casual restaurant image, perceived value, customer satisfaction, and behavioral intentions", International Journal of Hospitality Management, Vol. 27 No. 3, pp. 459-69.

Scott, J.E. (1994), "The measurement of information systems effectiveness: evaluating a measuring instrument", Proceedings of the Fifteenth International Conference on Information Systems, Vancouver, pp. 111-28.

Seiders, K., Berry, L.L. and Gresham, L.G. (2000), "Attention, retailers! How convenient is your convenience strategy?”, Sloan Management Review, Vol. 41 No. 3, pp. 79-89.

Sit, W.Y., Ooi, K.B., Lin, B. and Chong, A.Y.L. (2009), "TQM and customer satisfaction in Malaysia's service sector”, Industrial Management \& Data Systems, Vol. 109 No. 7, pp. 957-75.

Slater, S.F. and Narver, J.C. (2000), "Intelligence generation and superior customer value”, Journal of the Academy of Marketing Science, Vol. 28 No. 1, pp. 120-7.

Sweeney, J.C. and Soutar, G.N. (2001), "Consumer perceived value: the development of a multiple item scale”, Journal of Retailing, Vol. 77 No. 2, pp. 203-20.

Tsaur, S.H. and Wang, C.H. (2009), "Tip-collection strategies, service guarantees, and consumer evaluations of group package tours", Journal of Travel Research, Vol. 47 No. 4, pp. 523-34.

Tucci, L.A. and Talaga, J. (1997), "Service guarantees and consumers' evaluation of services", Journal of Services Marketing, Vol. 11 No. 1, pp. 10-18.

Tuu, H.H. and Olsen, S.O. (2009), "Food risk and knowledge in the satisfaction-repurchase loyalty relationship”, Asia Pacific Journal of Marketing and Logistics, Vol. 21 No. 4, pp. 521-36. 
Ulaga, W. and Chacour, S. (2001), "Measuring customer-perceived value in business market", Industrial Marketing Management, Vol. 30 No. 6, pp. 525-40.

Walsh, G., Evanschitzky, H. and Wunderlich, M. (2008), "Identification and analysis of moderator variables: investigating the customer satisfaction-loyalty link", European Journal of Marketing, Vol. 42 Nos 9/10, pp. 977-1004.

Wang, X., Zhang, J., Gu, C. and Zhen, F. (2009), "Examining antecedents and consequences of tourist satisfaction: a structural modeling approach”, Tsinghua Science and Technology, Vol. 14 No. 3, pp. 397-406.

Weiss, R., Feinstein, A.H. and Dalbor, M. (2005), "Customer satisfaction of theme restaurant attributes and their influence on return intent", Journal of Foodservice Business Research, Vol. 7 No. 1, pp. 23-41.

Wirtz, J. (1998), "Development of a service guarantee model", Asia Pacific Journal of Management, Vol. 15 No. 1, pp. 51-75.

Wirtz, J., Kum, D. and Lee, K.S. (2000), "Should a firm with a reputation for outstanding service quality offer a service guarantee?”, Journal of Service Marketing, Vol. 14 No. 6, pp. 502-12.

Zeithaml, V.A. (1988), "Consumer perceptions of price, quality, and value: a means-end model and synthesis of evidence", Journal of Marketing, Vol. 52 No. 3, pp. 2-22.

(The Appendix follows overleaf.)

\section{The effect of service convenience}

1441 
IMDS

110,9

Service convenience (SC)

Decision convenience (dc)

\section{2}

Access convenience (ac)

Transaction convenience (tc)

Benefit convenience (bc)

Post-benefit convenience (pbc)

Perceived service guarantee strength (PSGS)

Perceived service value (PSV)

Customer satisfaction (CS) dc1: The information I received from the restaurant made it easy for me to choose what to dine

dc2: Making up my mind about what I wanted to dine in the restaurant was easy

dc3: It was easy to get the information I needed to decide this restaurant to dine

ac1: There are various transportation ways can be chosen to reach the restaurant

ac2: It did not take much time to reach the restaurant

ac3: I was able to get to the restaurant's location quickly

tc1: The restaurant provides various ways for customers to make the payment

tc2: It was easy for me to complete the restaurant reservation

tc3: I was able to complete my purchase quickly

bc1: The restaurant's menu is easy for me to order meals

bc2: The time required to deliver food and beverage is appropriate

bc3: The operating hours of the restaurant meet my dining requirements

pbc1: The restaurant quickly resolved any problem I had with the services or meals

pbc2: The restaurant is able to resolve my problem I had with the services or meals

pbc3: It was easy for me to obtain information regarding new menu or promotion activities from the restaurant

psgs1: The restaurant employees make me feel they stand behind their service unconditionally

psgs2: The restaurant employees make me feel they really believes that the customer is always right

psgs3: The level of service that the restaurant claims to offer is more valuable to me than the level of service that the other restaurants offer

psgs4: I know the level of service I will receive before I go to the restaurant

psgs5: I have a clear understanding of the service quality the restaurant offers

psgs6: Employees are very quick to respond to my complains psv1: The money spent in this restaurant is lower than expected

psv2: The services offered by this restaurant are a very good value for the money spent

psv3: It is acceptable to spend money in this restaurant psv4: The price of this restaurant is not expensive for me psv5: The price of this restaurant is reasonable for this level of service

psv6: The price of this restaurant is acceptable

cs1: I am satisfied with my decision to dine at this restaurant cs2: My choice to dine at this restaurant was a wise one

(continued) 
cs3: I think I did the right thing when I chose to dine at this restaurant

cs4: I feel that my experience with this restaurant has been enjoyable

cs5: This facility is exactly what is needed for this service

cl1: I am very loyal to this restaurant

cl2: I would highly recommend this restaurant to my family and friends

cl3: I would continue to dine at this restaurant even if the price was higher

cl4: In the future, I intend to keep dining at this restaurant

c15: The next time I go to a restaurant, I am very likely to go to this restaurant

\section{The effect of service convenience}

1443

Table AI.

\section{Corresponding author}

Kuo-Chien Chang can be contacted at: kcchang@mail.chihlee.edu.tw 